\title{
Note on the Early Larvæ of Nephthys and Glycera.
}

\section{H. M. Fuchs, B.A.}

With 10 Text-figures.

THE larva of Nephthys was originally described by Claparède and Mecznikow (2) in 1868, from specimens obtained from the Plankton at Naples. Since then it has been figured by Fewkes (3), Häcker (5), and Gravely (4). The larva of Glycera is, as far as I am aware, hitherto undescribed.

The larvæ described below were reared in the laboratory at Plymouth, at the suggestion of Dr. Cresswell Shearer, from artificially fertilized eggs. Both Nephthys Hombergi* and Glycera convolute can be obtained from the sand in Jennycliff Bay at low water. Nephthys occurs more commonly than Glycera, but large specimens are not frequent. On the other hand, very young specimens are completely absent. It is at present altogether unknown what becomes of the young of these worms from the time when they sink down from the Plankton until they grow to about an inch in length. From June to August most of the larger individuals contain ripe sperm and ova, which are frequently discharged in captivity, within a day or two from the date of capture. It was found unnecessary, however, to wait until the generative products were shed naturally. The method of procedure was as follows: The worms were slit up with a pair of scissors and placed in "outside" sea-water in sterilized finger-bowls, the males being kept apart from the females. As soon as the sexual products emerged from the body cavity the worm was removed, several being treated in this manner to ensure the presence of ripe eggs. A few drops of liquid from the suspension of sperm was then added to the bowl of eggs and the latter stirred and allowed to settle. Wilson (9) has stated for Nereis and Treadwell (8) for Podarke that if the eggs are cut out of the body of the female, segmentation is irregular. This is not the case with Nephthys and Glycera. As soon as the larvæ swam to the surface they were pipetted off and placed in jars of filtered sea-water.

All attempts to feed the larvæ failed, and in consequence, although they could be kept alive for three weeks or a month, after about

* It is just possible that a few small specimens of $N$. cacca were included with the N. Hombergi. 
fourteen days no further development took place. I have to thank Dr. Allen for providing me with pure cultures of Diatoms and other Algæ, but I was unable to find any food which the larvæ would eat. Nothing is easier than the rearing of Serpulids in a laboratory, and especially is this the case with regard to Pomatoceros, which is a hardy shore form, found growing even at the mouths of drains. It breeds naturally and in great profusion in the tanks at Naples, the young worms settling down and forming their tubes without having any care bestowed on them. But very few of the free-living Polychaetes have been reared to a late stage. Chaetopterus is an example of one which has been raised (Allen and Nelson 1) and Lillie (6) was successful with Arenicola. I have found it very easy to rear the larvæ of Nereis dumerilii, which are derived from yolky eggs, as far as thirty segments or more. Quite otherwise, however, is it with those free-living Polychaetes which have a pelagic larva. It would thus seem that it is possible to rear from the egg such forms as the Serpulids, which have a typical Trochophore, and those which have yolky eggs, but no method has as yct been devised by which the majority of the errant forms can be fed and raised.

The egg of Glycera is discoidal, and it does not swell up in seawater. It is granular, but comparatively transparent, with a lighter coloured nucleus. The egg of Nephthys is also flattened at the poles, but is opaque. The cleavage is equal.

Unlike the larva described by Claparède and Mecznikow (2), the larva of Nephthys Hombergi is granular and so opaque as to render the study of the internal organs in optical sections very difficult. Neither in shape nor in transparency can it be called a typical trochophore. An early stage is shown in Fig. 1. The upper hemisphere is more conical

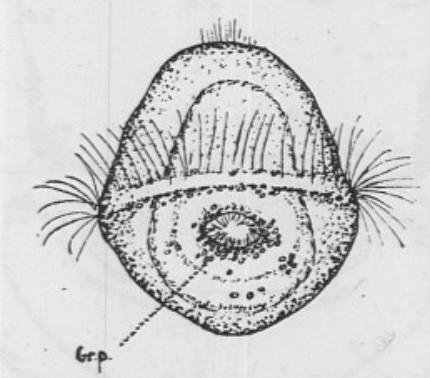

Fig. 1.-Larva of Nephthys. 2 days.

From the ventral aspect. $b r . p .-$ Brown pigment.

and of smaller diameter than the lower, and is surmounted by an apical patch of cilia. The mouth is situated mid-ventrally on the lower hemisphere, and strong cilia can be seen working within it. Brown 
pigment is scattered on the surface in small chromatophores, which ar concentrated below the trochal ring and round the mouth. Fig.

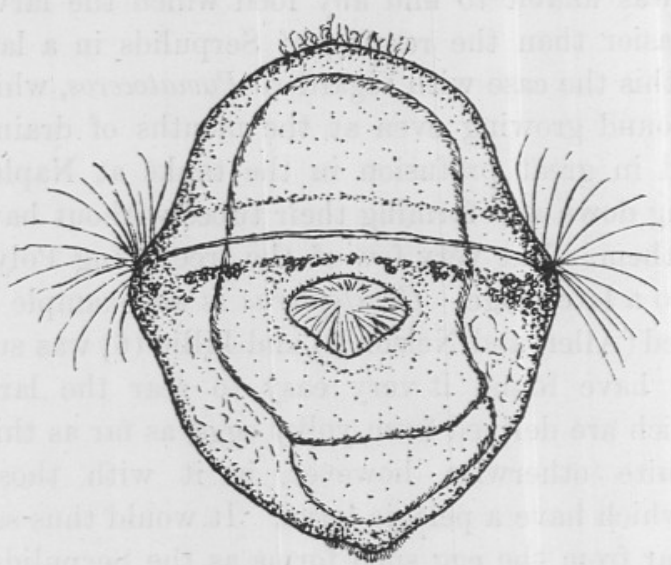

Fig. 2.-Larva of Nephthys, 6 days.

From the ventral aspect.

shows a later stage, the general shape of the larva being the same : before. The alimentary canal is divided into stomach and intestin and there is an anal patch of cilia. Fig. 3 shows a trochophore of fou

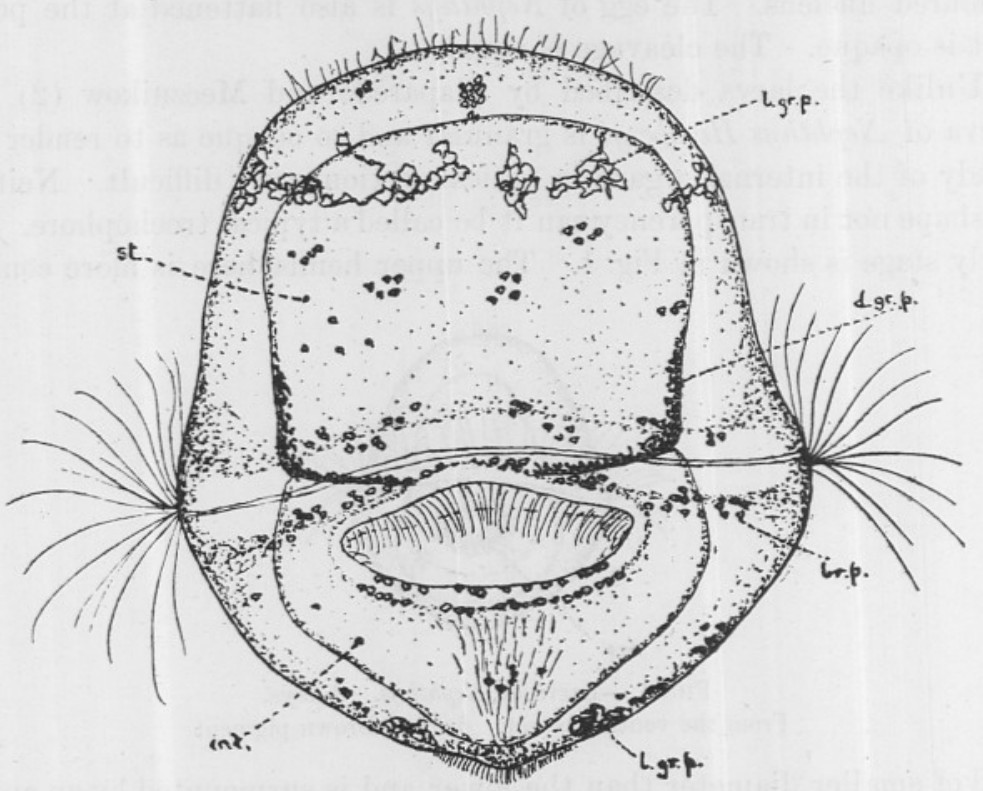

Fig. 3.-Larva of Nephthys. 14 days.

From the ventral aspect. $b r . p .-$ Brown pigment. $d . g r . p .-$ Dark green pigment. int.-Intestine. $l$. gr. $p$.-Light green pigment. st.-Stomach. 
teen days old. The upper hemisphere is larger and blunter than the lower. There is a patch of cilia extending from the lower lip of the mouth towards the anus, which is terminal. The apical cilia are usually motionless. Light green pigment has appeared in an incomplete band round the upper hemisphere, and a pair of patches on either side of the anus. These latter are characteristic of the larva of Nephthys.(3). The large stomach, which fills the greater part of the upper hemisphere, has a dark green pigment in its basal walls, the remainder of the gut being yellow in colour. The intestine is sac-like.

The larva described above differs very much from that figured by Claparède and Mecznikow (2). It resembles in some points that of Fewkes (3), but is of a different shape. Häcker (5) and Gravely (4) described the Metatrochophore and later stages only.

Swimming blastulæ of Glycera convoluta appear some ten hours after fertilization, and the trochal ring is formed in twenty-four hours. An early larva is shown in Fig. 4. It is spherical and granular with a

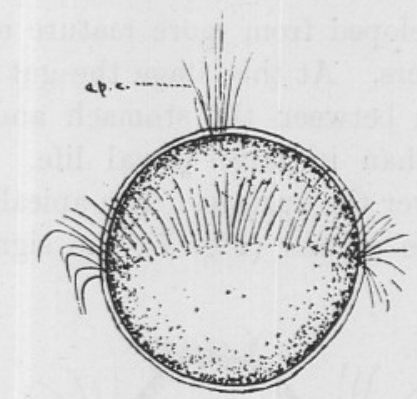

FIG. 4.-Larva of Glycera. 26 hours. $a p . c .-$ Apical cilia.

ciliated trochal ring and an apical tuft of long cilia. Fig. 5 shows

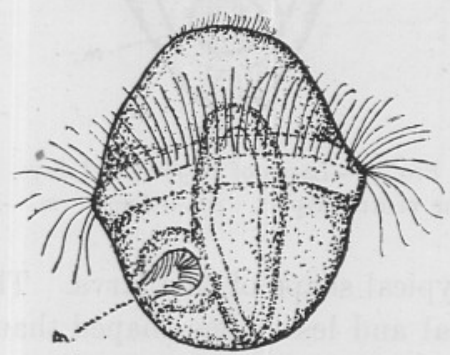

FIG. 5.-Larva of Glycera. 58 hours. Left side view. m.-Mouth. 
a somewhat later larva in lateral optical section. The larva is more elongated and the apical patch has become diffuse, without any long cilia. The buccal aperture is seen to be strongly ciliated. Fig. 6 is a

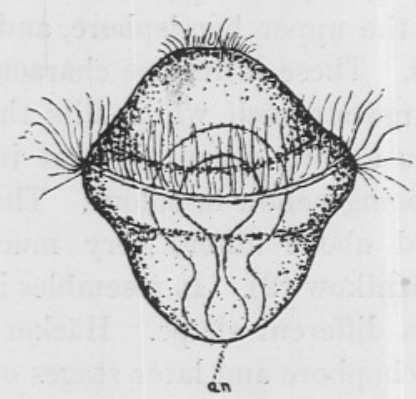

Fig. 6.-Larva of Glycera. 3 days.

From the dorsal aspect. an.-Anus.

trochophore of three days old. Little weight can, however, be attached to the ages of the larvæ, as in the same culture some larvæ, probably those which have developed from more mature eggs, will grow much more rapidly than others. At this stage the gut has thick walls, and there is a constriction between the stomach and intestine, which is much more evident than in later larval life. A very light green pigment is scattered over the surface. The apical patch seems to contain a pair of vibratile organs (Fig. 7), the significance of which is unknown.

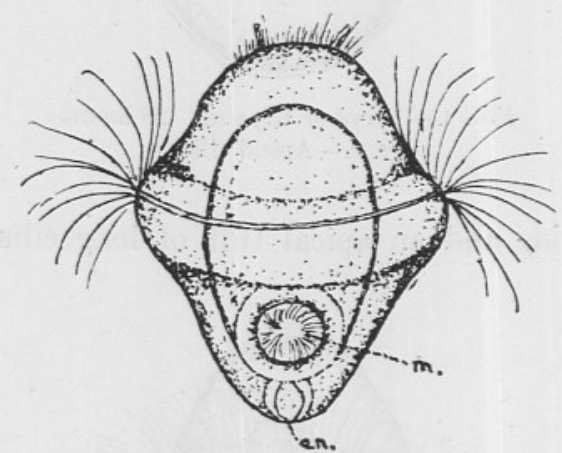

Fig. 7.-Larva of Glycera. 4 dajs.

From the ventral aspect. an.-Anus. $m,-$ Mouth.

Fig. 8 shows the typical shape of this larva. The upper hemisphere is rather more conical and less dome-shaped than the lower. This is the reverse of the condition in a typical trochophore. Large and granular green pigment corpuscles are scattered over the surface. They are 


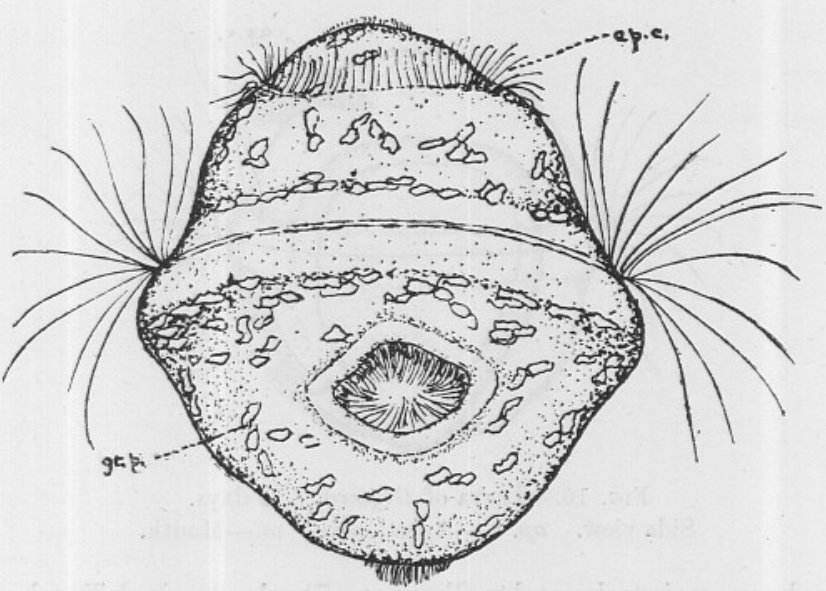

Fig. 8.-Larva of Glycera. 3 days.

From the ventral aspect. $a p . c .-$ Apical cilia. $g r . p .-$ Green pigment.

more numerous on the lower hemisphere, and especially below the trochal ring. The apical cilia have assumed the form of a ring round the upper hemisphere. This band is situated in a slight depression of the surface and is incomplete dorsally (Fig. 9). There is a patch

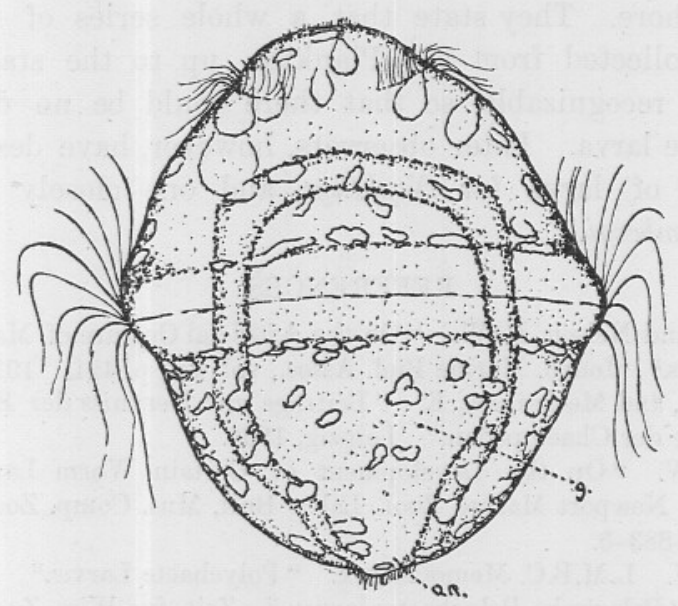

FIG. 9.-Larva of Glycera. 4 days.

From the dorsal aspect. an.-Anus. g.-gut.

of cilia extending from the lower lip to the anus (Fig. 10). The mouth is diamond shaped and is situated mid-ventrally on the lower hemisphere. The gut is large and sac-like, without any definite division into stomach and intestine.

NEW SERIES.-VOL. IX, NO. 2. OCTOBER, 1911. 


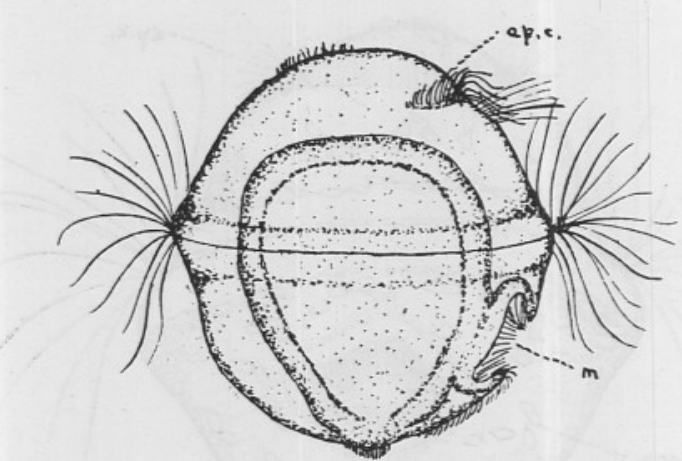

FIG. 10.-Larva of Glycera. 10 days.

Side view. ap. c.-Apical cilia. m.-Mouth.

As has been pointed out by Shearer (7), the typical Trochophore is confined to a very limited number of Annelids, occurring, in fact, only in Serpulids and Polygordius. The larvæ of the remaining forms, which have a pelagic stage, mostly resemble the two described above. They differ from the true Trochophore in form, opacity, shape of the gut, in the absence of a head-kidney and in the small amount of blastocoele. The early Nephthys larva figured by Claparède and Mecznikow (2), however, seems to approach closely to the form of a true Trochophore. They state that a whole series of intermediate forms were collected from the Plankton, up to the stage when the bristles were recognizable, so that there could be no doubt of the identity of the larva. Later observers, however, have described quite another type of larva for Nephthys, and one closely approaching that of $N$. Hombergi.

\section{REFERENCES.}

1. Allen, E. J., and Nelson, E. W. "On the Artificial Culture of Marine Plankton Organisms." Journ. Marine Biol. Assoc., vol. viI, p. 421. 1910.

2. Claparède, E., and Mecznikow, E. "Beiträge zur Kentniss der Entwickelungsgeschichte der Chaetopoden." Leipzig, 1868.

3. Fewkes, J. W. "On the Development of Certain Worm Larvæ." Studies from the Newport Marine Zool. Lab. Bull. Mus. Comp. Zool. Harv. Coll., vol. II. 1883-5.

4. Gravely, F. H. L.M.B.C. Memoirs, xIx. " "Polychaete Larvæ." 1909.

5. Häcker, V. "Pelagische Polychaetenlarven." Zeit. fur Wiss. Zool., 1897, p. 74.

6. Lillie, R. S. "The Structure and Development of the Nephridia of Arenicola cristata." Mittheil, a.d. zool. Sta. zu. Neapel, 17 Bd., 3 Heft, 1905.

7. Shearer, C. "On the Development and Structure of the Trochophore of Hydroides uncinatus." Q. J. Micr. Sci., vol. LvI, p. 543. 1911.

8. Treadwell, A. "The Cytogeny of Podarke obscura." Journ. Morph., vol. xvII, p. 399. 1901.

9. Wilson, E. B. "The Cell-lineage of Nereis." Journ. Morph., vol. vi, p. 361. 1892. 